\title{
White-light upconversion emission of lanthanide double-doped oxide nanoparticles via defect state luminescence of $\mathrm{ZnO}$
}

\author{
Yuemei $\mathrm{Li}^{1}$, Yongmei $\mathrm{Li}^{2}$, Rui Wang ${ }^{1 *}$ and Yanling $\mathrm{Xu}^{1}$
}

\begin{abstract}
The white upconversion luminescence (UCL) of upconversion nanoparticles (UCNPs) is mainly made up of the color red, green and blue. Interestingly, the white-light-emitting UCNPs can be obtained via a complex method of tridoping lanthanide ions such as $\mathrm{Yb}^{3+}, \mathrm{Er}^{3+}$, and $\mathrm{Tm}^{3+}$. We herein report that an excellent white UCL can be obtained from $\mathrm{Yb} / \mathrm{Tm}$ double-doped $\mathrm{ZnO}$. In this system, the blue and red UCL-emissions around 475 and $652 \mathrm{~nm}$ originate from ${ }^{1} \mathrm{G}_{4} \rightarrow{ }^{3} \mathrm{H}_{6}$ and ${ }^{1} \mathrm{G}_{4} \rightarrow{ }^{3} \mathrm{~F}_{4}$ transition of $\mathrm{Tm}^{3+}$, respectively, and the green one can be attributed to the defect states (oxygen vacancies) luminescence (DSL) of the $\mathrm{ZnO}$ host. Meanwhile, the fine nanostructure of $\mathrm{ZnO}: \mathrm{Yb} / \mathrm{Tm}$ is prepared by adjusting the concentration of $\mathrm{OH}^{-}$. Particularly, the one dimentional pencil-shaped nanorods with high aspect ratio achieve a strong green DSL emission due to the high concentration of oxygen vacancy. The oxygen vacancy defects play an irreplaceable role in affecting the intensities of blue and red UCL by acting as the intermediate state in the energy transfer process. More importantly, we demonstrate that the DSL and UCL can be combined into systems, paving a new road for obtaining the white UCL emission.
\end{abstract}

Keywords: white upconversion luminescence, pencil-shaped $\mathrm{ZnO}: \mathrm{Yb} / \mathrm{Tm}$ nanorods, defect states luminescence

\section{INTRODUCTION}

Recently, lanthanide $\left(\mathrm{Ln}^{3+}=\mathrm{Yb}, \mathrm{Er}, \mathrm{Tm}\right.$, and $\left.\mathrm{Ho}\right)$ codoped upconversion nanoparticles (UCNPs) have attracted significant attention due to their outstanding energy transfer (ET) properties. The doping of $\mathrm{Ln}^{3+}$ ions can convert the near-infrared (NIR) into visible light. The NIR excitation can penetrate the skin, which has potential biological applications, such as bioimaging and multi- functional biological probes [1-15]. The white UCL has a broad range of emission wavelengths, including blue, green, and red emissions, generating a large library of spectral region that can be used for multiplexed biological labeling and encoding [16,17]. However, the relatively low efficiency of white UCL sources still poses a challenge to researchers today. It is well-known that the efficiency of white UCL is highly dependent on host matrix, particle morphology, crystallite phase, and lanthanide dopants [18-23]. Therefore, the study of their host matrix is important for obtaining a good white UCL emission and white light [24].

Previous studies on host materials have been focused on various semiconductor nanocrystals such as $\mathrm{Gd}_{2} \mathrm{O}_{3}$ and $\mathrm{ZnO}[25,26]$. A significant improvement in ET from the semiconductor nanocrystals (SNC) has led to an efficiently sensitized UCL emission. Meanwhile, the inefficient absorptions of the forbidden $4 \mathrm{f}-4 \mathrm{f}$ transitions of Ln ions have been overcome [27]. With the doped $\left(\mathrm{Eu}^{3+}\right) \mathrm{Y}_{2} \mathrm{O}_{3}$ nanocrystals, it was reported that the UCL intensity of SNC was enhanced via the ET from the excited host to the $\mathrm{Eu}^{3+}$ ions [28]. This phenomenon was explained by host sensitization, which occurred due to energy level fitting in the crystal field structure of $\mathrm{Ln}^{3+}$ ions in the SNC lattice sites [29]. ZnO SNCs are the most common host materials of a UCL system, owing to their electronic structures and optical properties. In particular, $\mathrm{ZnO}$ nanorods have attracted great interest due to their high surface-to-volume ratio and excellent crystallite quality $[30,31]$. However, it is difficult to incorporate $\mathrm{Ln}^{3+}$ ions into the $\mathrm{ZnO}$ lattice due to the large mismatch of ionic radii between $\mathrm{Ln}^{3+}$ and $\mathrm{Zn}^{2+}$ ions and the resulting imbalance in charge [32,33].

\footnotetext{
${ }^{1}$ School of Chemistry and Chemical Engineering, Harbin Institute of Technology, Harbin 150001, China

${ }^{2}$ Key Laboratory of Hormones and Development (Ministry of Health), Tianjin Key Laboratory of Metabolic Diseases, Tianjin Metabolic Diseases Hospital \& Tianjin Institute of Endocrinology, Tianjin Medical University, Tianjin 300070, China

* Corresponding author (email: wangrui001@hit.edu.cn)
} 


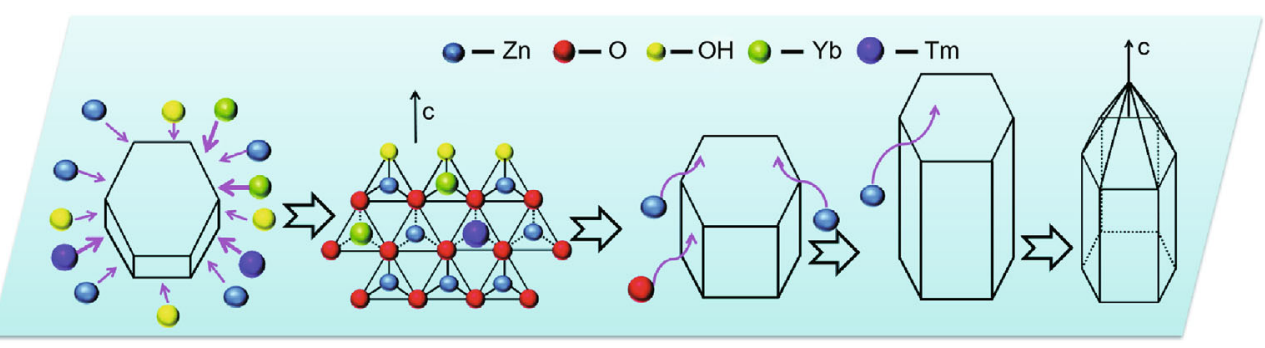

Scheme 1 Schematic illustration of the oriented growth mechanism of $\mathrm{ZnO}: \mathrm{Yb} / \mathrm{Tm}$ by controlling the concentration of $\mathrm{OH}^{-}$.

In this study, we proposed a hydrothermal wet chemical method to synthesize pencil-shaped $\mathrm{ZnO}: \mathrm{Yb} / \mathrm{Tm}$ nanorods, and demonstrated a novel strategy by which the defect states (oxygen vacancies) luminescence (DSL) of $\mathrm{ZnO}$ and intra- $4 \mathrm{f}$ electronic transitions of $\mathrm{Ln}^{3+}$ were utilized to achieve the white UCL emission in $\mathrm{a} \mathrm{Yb}^{3+}$ and $\mathrm{Tm}^{3+}$ co-doped ZnO SNC [34]. It is well-known that the efficiency of a white UCL depends on the concentrations of $\mathrm{Ln}^{3+}$ ions [35]. Here, for the first time, a white UCL is obtained through the double doping of $\mathrm{Ln}^{3+}$ ions into the $\mathrm{ZnO}$ SNCs. Specifically, the green UCL emission is obtained from the pencil-shaped $\mathrm{ZnO}$ by changing the concentrations of oxygen vacancies, and the cooperative emission of $\mathrm{Yb}^{3+}-\mathrm{Tm}^{3+}$ provides the blue and red UCL emission.

\section{EXPERIMENTAL SECTION}

\section{Synthesis}

The hexagonal $\mathrm{ZnO}: \mathrm{Yb} / \mathrm{Tm}$ SNCs were synthesized via the hydrothermal method [30]. In our previous studies, we showed that the reaction time and temperature, the size of the samples, and the concentration of the doping ions affect the UCL properties of $\mathrm{Yb} / \mathrm{Tm} / \mathrm{ZnO}$ nanoparticles [30-36]. In order to analyze the functional dependence of the morphology, three sets of samples were prepared with different concentrations of $\mathrm{OH}^{-}$. While the molar concentrations of $\mathrm{Yb}^{3+}$ and $\mathrm{Tm}^{3+}$ were fixed at 7 and $0.5 \mathrm{~mol} \%$ respectively, the $\mathrm{OH}^{-}$concentrations were 1,2 and $3 \mathrm{~mol} \mathrm{~L}^{-1}$ for the first, second, and third set, respectively [30]. A mixture of $\mathrm{Zn}\left(\mathrm{NO}_{3}\right)_{2} \cdot 6 \mathrm{H}_{2} \mathrm{O}, \mathrm{Yb}$ $\left(\mathrm{NO}_{3}\right)_{3} \cdot 5 \mathrm{H}_{2} \mathrm{O}$ and $\mathrm{Tm}\left(\mathrm{NO}_{3}\right)_{3} \cdot 5 \mathrm{H}_{2} \mathrm{O}$ was dissolved by stirring for $1.5 \mathrm{~h}$ at $25^{\circ} \mathrm{C}$. Then the solution was transferred to reaction kettle $(30 \mathrm{~mL})$ and reacted at $150^{\circ} \mathrm{C}$ for $24 \mathrm{~h}$.

\section{Characterization}

The sample morphologies and sizes were analyzed by scanning electron microscopy (SEM; SU8000, Hitachi) and the transmission electron microscopy (TEM). The phase and structure of the sample were analyzed by X-ray diffraction (XRD) with a Rigaku $\mathrm{Cu}-\mathrm{Ka}$ radiation $(\lambda=$ $1.54 \AA$ ). The upconversion emission spectra of the $\mathrm{Yb}^{3+} /$ $\mathrm{Tm}^{3+} / \mathrm{ZnO}$ nanoparticles were recorded using a $980 \mathrm{~nm}$ excitation. The color coordinates of the samples were calculated by the 1931 CIE (Commission Internationale de L'Eclairage France) system. All measurements were performed at room temperature.

\section{RESULTS AND DISCUSSION}

\section{Structural characterization}

As shown in Scheme 1, the size change and oriented growth of $\mathrm{ZnO}: \mathrm{Yb} / \mathrm{Tm}$ UCNPs can be controlled by the concentration of $\mathrm{OH}^{-}$. Fig. 1 shows the SEM and TEM images of the as-prepared $\mathrm{ZnO}: \mathrm{Yb} / \mathrm{Tm}(7 / 0.5 \mathrm{~mol} \%)$ at different concentrations of sodium hydroxide $(\mathrm{NaOH})$ from 1 to $3 \mathrm{~mol} \mathrm{~L}^{-1}$. For the doping of $1 \mathrm{~mol} \mathrm{~L}^{-1} \mathrm{NaOH}$, the SEM and TEM images (Fig. 1a, d) show the $\mathrm{ZnO}: \mathrm{Yb} /$ Tm UCNP composed of hexagonal microrods. When the concentration of $\mathrm{NaOH}$ was $2 \mathrm{~mol} \mathrm{~L}^{-1}$ (Fig. 1b, e), highquality uniform pencil-shaped nanorods of $\mathrm{ZnO}: \mathrm{Yb} / \mathrm{Tm}$ UCNPs with pure hexagonal phase were achieved, and their sizes decreased from 210.4 to $96.3 \mathrm{~nm}$ (Fig. 1g). With $3 \mathrm{~mol} \mathrm{~L}^{-1} \mathrm{NaOH}$, the UCNPs show two dimensional (2D) structural growth such as dendrite and large-scale snowflake particles (Fig. 1c, f), and their sizes increase from 96.3 to $304.3 \mathrm{~nm}$ (Fig. 1g). Moreover, the energy dispersive X-ray spectrometry (EDS) analysis on pencilshaped UCNPs shows the presence of $\mathrm{Zn}, \mathrm{Tm}$, and $\mathrm{Yb}$ elements only (Fig. $1 \mathrm{~h}$ ), proving no impurity. These results demonstrate that the size and oriented growth of $\mathrm{ZnO}: \mathrm{Yb} / \mathrm{Tm}$ UCNPs can be controlled by the doped $\mathrm{OH}^{-}$ contents. The growth process of $\mathrm{ZnO}: \mathrm{Yb} / \mathrm{Tm}$ includes the formation of $\mathrm{Zn}(\mathrm{OH})_{4}{ }^{2-}$, the dehydration of $\mathrm{Zn}(\mathrm{OH})_{4}{ }^{2-}$ at the crystal interface, and the substitution of lanthanide ions $\left(\mathrm{Yb}^{3+} / \mathrm{Tm}^{3+}\right)$. The sample growth rate is related to the number of $\mathrm{OH}^{-}$at the interface of $\mathrm{ZnO}_{4}{ }^{6-}$. The hydroxyl ion tends to stabilize the zinc ion and affects the direction 

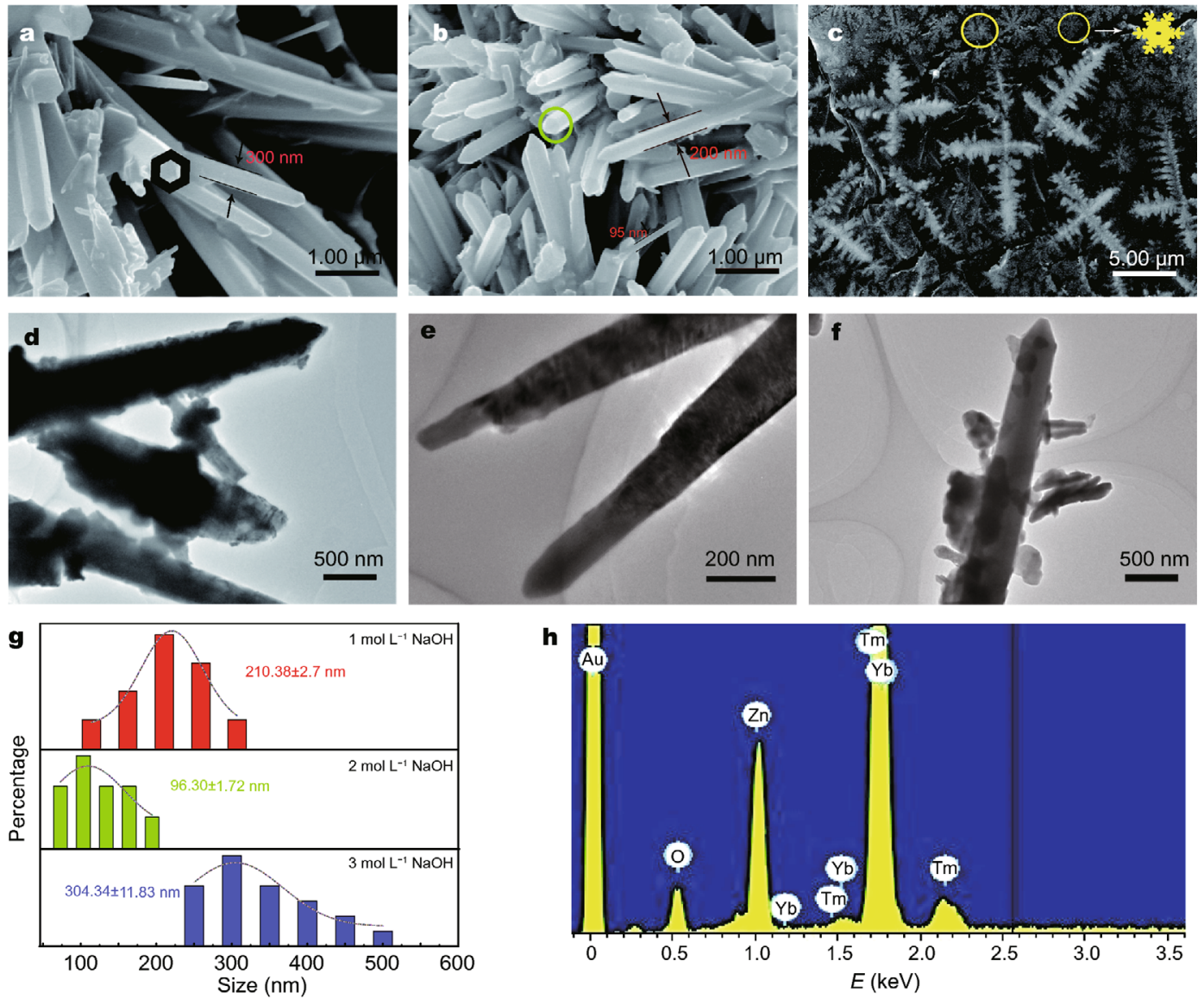

Figure $1(\mathrm{a}-\mathrm{c})$ Typical SEM images and (d-f) the TEM images of $\mathrm{ZnO}: \mathrm{Yb} / \mathrm{Tm}$ with $\mathrm{OH}^{-}$contents of 1,2 and 3 mol $\mathrm{L}^{-1}$ respectively, (g) the diameter size of $\mathrm{ZnO}: \mathrm{Yb} / \mathrm{Tm}$ nanorods for increased $\mathrm{OH}^{-}$contents, (h) EDS of the as-prepared samples shown in (b).

of crystal growth, resulting in a change in the morphology. At relatively low concentrations of $\mathrm{OH}^{-}(1$ and $2 \mathrm{~mol} \mathrm{~L}^{-1}$ ), the mobility of $\mathrm{Zn}^{2+}$ was sufficient and the diffusion length was enough to allow radial growth (Scheme 1). As the concentration of $\mathrm{NaOH}$ was increased, the zinc ion had low mobility because of the presence of more hydroxyl groups, which enabled the 2D growth of the sample. Therefore, the $\mathrm{ZnO}: \mathrm{Yb} / \mathrm{Tm}$ UCNPs exhibited a snowflake-like morphology (Fig. 1c, f).

According to the coordination polyhedron rule for growth habit of $\mathrm{ZnO}$, the fastest growth rate is observed in the (0001) plane. Therefore, the growth of $c$-plane(0001) nanorods (scheme 1) in our experiment is consistent with the theory. The TEM image of a single nanorod (Fig. 2b), taken from Fig. 2a, has a lattice spacing of $5.23 \AA$, matching well with the (002) crystal plane of the hexagonal phase (Fig. 2c), which belongs to the (0001) planes. Fig. $2 \mathrm{c}$ shows the XRD patterns of the as-prepared samples with different concentrations of $\mathrm{NaOH}$. The $\mathrm{XRD}$ peaks are consistent with hexagonal wurtzite $\mathrm{ZnO}$
(JCPDS Card No. 36-1451) and confirm the absence of any other impurity phase. Furthermore, the $\mathrm{ZnO}: \mathrm{Yb} / \mathrm{Tm}$ (002) peak, which is directly related to the $1 \mathrm{D}$ growth of $\mathrm{ZnO}: \mathrm{Yb} / \mathrm{Tm}$ nanorods, shows a significant difference in the intensity with increasing $\mathrm{OH}^{-}$concentration. These results show that the sample has a strong diffraction peak and a highly preferential orientation in the (002) crystallographic direction when the $\mathrm{OH}^{-}$content reaches $2 \mathrm{~mol} \mathrm{~L}^{-1}$. Therefore, the $1 \mathrm{D}$ growth of $\mathrm{ZnO}: \mathrm{Yb} / \mathrm{Tm}$ (pencil-shaped nanorods) can be controlled by changing the concentration of $\mathrm{OH}^{-}$.

\section{White upconversion emission of $\mathrm{ZnO}: \mathrm{Yb} / \mathrm{Tm}$}

The white UCL emission has many potential applications in various fields such as biological labeling, imaging, and biological probes. However, it is still a great challenge to fine-tune the upconversion color output. In order to further demonstrate the white UCL properties of $\mathrm{ZnO}$ : $\mathrm{Yb} / \mathrm{Tm}$ UCNPs with different $\mathrm{NaOH}$ concentrations, we performed experiments with a laser irradiation of 

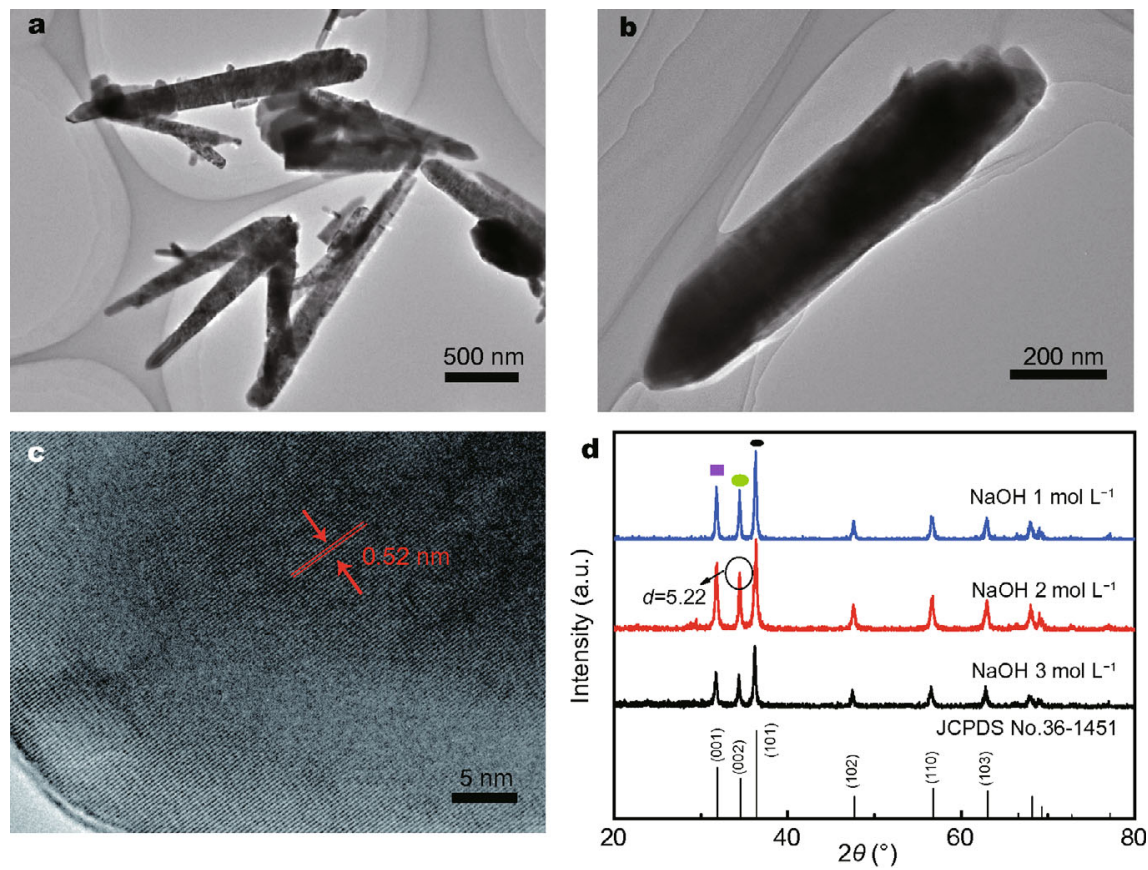

Figure 2 TEM images of $\mathrm{ZnO}: \mathrm{Yb} / \mathrm{Tm}$ nanorods with $2 \mathrm{~mol} \mathrm{~L}^{-1}$ of $\mathrm{OH}^{-}$with scale bar of $500 \mathrm{~nm}$ (a) and $200 \mathrm{~nm}$ (b), (c) high-resolution TEM image taken from a single particle in (b), (d) XRD patterns of the $\mathrm{ZnO}: \mathrm{Yb} / \mathrm{Tm}\left(7 / 0.5 \mathrm{~mol} \%\right.$ ) by doping different $\mathrm{OH}^{-}$contents.
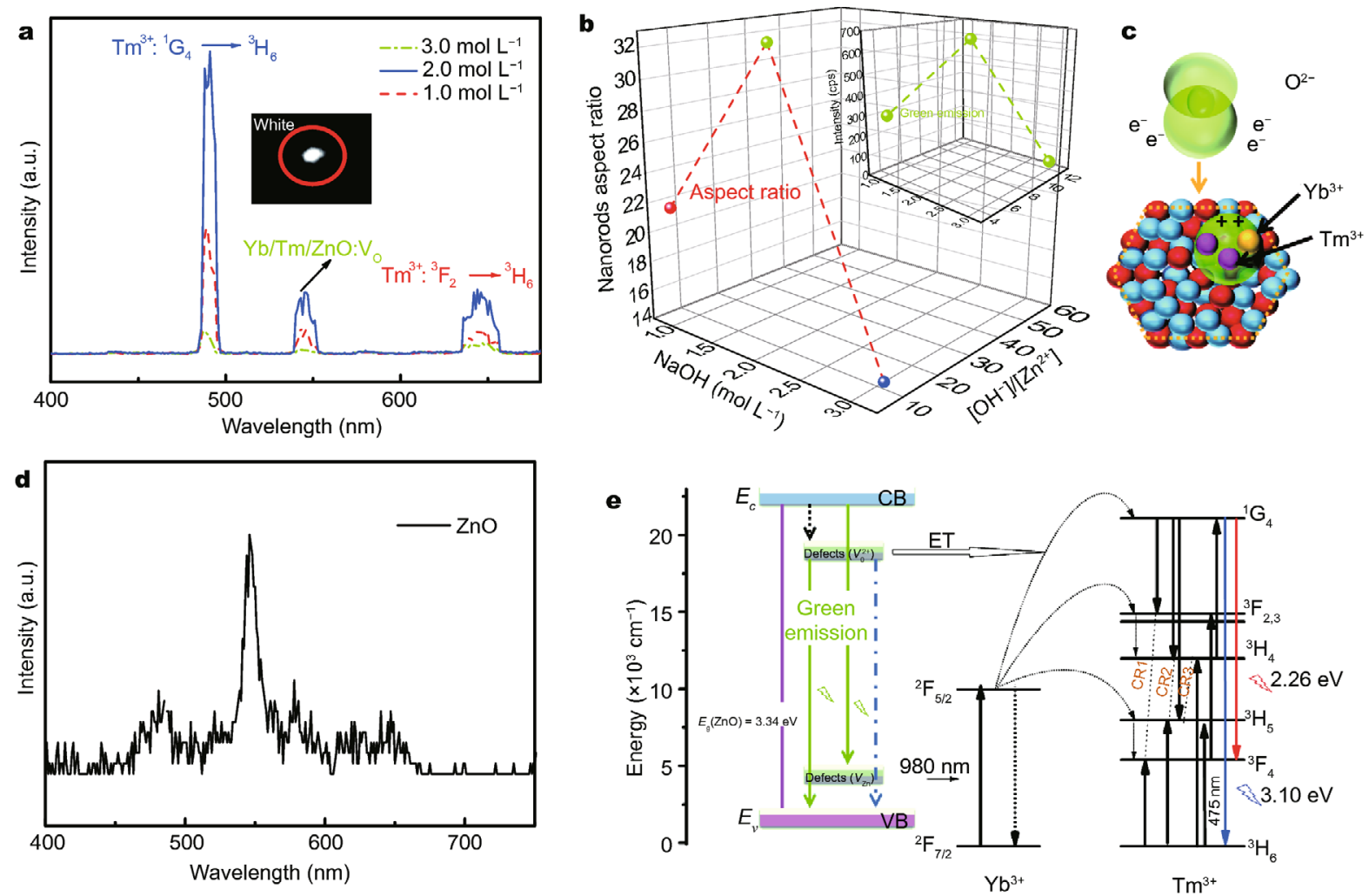

Figure 3 (a) UCL spectra of the samples with different content of $\mathrm{OH}^{-}$, and the inset is a digital photograph; (b) the aspect ratio and intensity of green emission with different content of $\mathrm{OH}^{-}$; (c) the change in surface charge density caused by replacing the $\mathrm{Yb}^{3+} / \mathrm{Tm}^{3+}$ in the host lattice; (d) $\mathrm{UCL}$ spectra of the host $\mathrm{ZnO}$ with $2 \mathrm{~mol} \mathrm{~L}^{-1}$ of $\mathrm{OH}^{-}$; (e) DSL and UCL mechanisms under the excitation of $980 \mathrm{~nm}$ laser. 

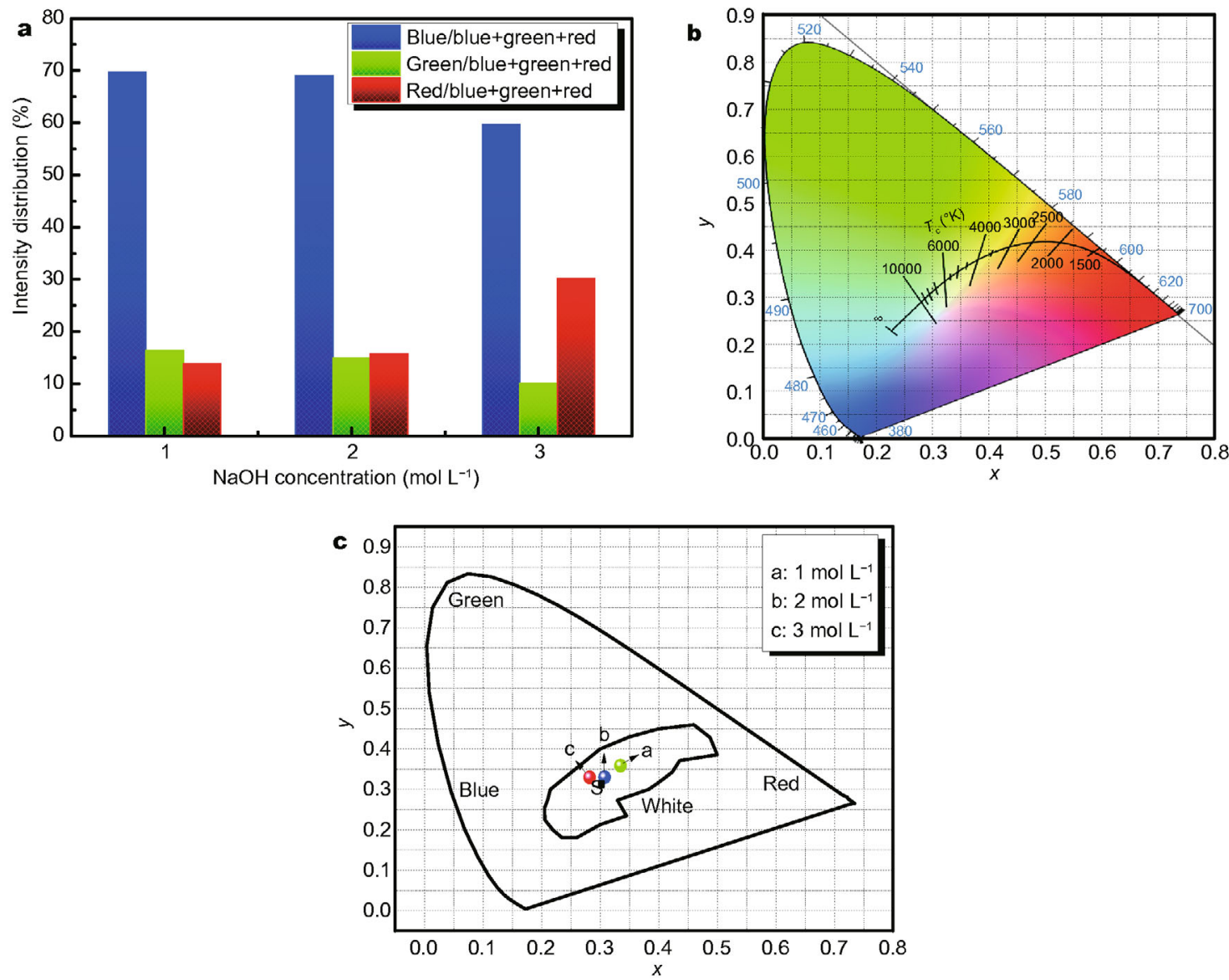

Figure 4 (a) $I_{\mathrm{B}} / I_{(\mathrm{B}+\mathrm{G}+\mathrm{R})}, I_{\mathrm{G}} / I_{(\mathrm{B}+\mathrm{G}+\mathrm{R})}$ and $I_{\mathrm{R}} / I_{(\mathrm{B}+\mathrm{G}+\mathrm{R})}$ intensity distributions, (b, c) chromaticity diagram for the $\mathrm{ZnO}$ : $\mathrm{Yb} /$ Tm with different concentrations of $\mathrm{OH}^{-}$under $980 \mathrm{~nm}$ excitation.

$980 \mathrm{~nm}$. Fig. 3a shows the upconversion spectra of $\mathrm{ZnO}$ : $\mathrm{Yb} / \mathrm{Tm}$ UCNPs at different concentrations of $\mathrm{NaOH}$. As can be seen, these samples emit blue, red, and green UCL around 475, 652, and $545 \mathrm{~nm}$, respectively (Fig. 3a). The blue and red UCL originate from ${ }^{1} \mathrm{G}_{4} \rightarrow{ }^{3} \mathrm{H}_{6}$ and ${ }^{1} \mathrm{G}_{4} \rightarrow{ }^{3} \mathrm{~F}_{4}$, respectively (Fig. 3e). On the other hand, the green $\mathrm{UCL}$ can be ascribed to the DSL. The UCL emission intensity of $\mathrm{ZnO}: \mathrm{Yb} / \mathrm{Tm}$ reaches a maximum with $2 \mathrm{~mol} \mathrm{~L}^{-1} \mathrm{OH}^{-}$, indicating an ET process from the host $\mathrm{ZnO}$ to $\mathrm{Yb}^{3+}$ and $\mathrm{Tm}^{3+}$, while the defect states (oxygen vacancies) act as the intermediate states. In addition, the aspect ratio of nanorods and the intensity of green UCL peak at this $\mathrm{OH}^{-}$ concentration (Fig. 3b). This indicates that the high aspect ratio of pencil-shaped nanorods produces a high quantity of oxygen vacancies, which prefers the DSL process and a strong green UCL emission is consequently observed. Meanwhile, the substitutions of $\mathrm{Zn}^{2+}$ by $\mathrm{Yb}^{3+}$ and $\mathrm{Tm}^{3+}$ generate positive dipoles pointing outward on the crystal surface (to balance the charge), subsequently attracting oxygen ions in the periphery, which can greatly accelerate the formation of oxygen vacancies from the solution to the grain, and therefore promote the intensity of green UCL emission (Fig. 3c). In order to further determine the source of the green UCL emission band centered around $545 \mathrm{~nm}$ under the excitation with $980 \mathrm{~nm}$, the UCL emission spectra of the host $\mathrm{ZnO}$ nanoparticles were recorded. The corresponding spectrum (Fig. 3d) shows one emission band centered at $545 \mathrm{~nm}$. Therefore, the band originates from the DSC of $\mathrm{ZnO}$ nanoparticles.

The digital photograph (inset of Fig. 3a) shows white color. In order to further investigate the white UCL intensity of $\mathrm{ZnO}: \mathrm{Yb} / \mathrm{Tm}$ with different $\mathrm{OH}^{-}$concentrations, the color distributions of samples are analyzed. Fig. $4 \mathrm{a}$ shows the intensity distributions of $I_{\mathrm{B}} / I_{(\mathrm{B}+\mathrm{G}+\mathrm{R})}, I_{\mathrm{G}} / I_{(\mathrm{B}+\mathrm{G}+\mathrm{R})}$, and $I_{\mathrm{R}} / I_{(\mathrm{B}+\mathrm{G}+\mathrm{R})}$ in the range from 400 to $750 \mathrm{~nm}$, where $\mathrm{B}$, $\mathrm{G}$, and $\mathrm{R}$ represent the blue, green, and red emissions, respectively. It was found that the emission proportion of 
$I_{\mathrm{R}} / I_{(\mathrm{B}+\mathrm{G}+\mathrm{R})}$ increased, while $I_{\mathrm{B}} / I_{(\mathrm{B}+\mathrm{G}+\mathrm{R})}$ and $I_{\mathrm{G}} / I_{(\mathrm{B}+\mathrm{G}+\mathrm{R})}$ decreased gradually with increasing $\mathrm{OH}^{-}$concentration. This result can be attributed to the morphology of the samples, because the formation of dendrite structures (see Fig. 1) increases as the concentration of $\mathrm{OH}^{-}$increases. Moreover, to analyze the color composition of the white emissions that the naked eye perceives, the color coordinates were calculated from Fig. 3a via the 1931 CIE (Commission Internationale de I'Eclairage France) system. As illustrated in Fig. 4b, c, the white UCL can be obtained by increasing the concentration of $\mathrm{OH}^{-}$from 1 to $3 \mathrm{~mol} \mathrm{~L}^{-1}$, and the chromaticity coordinates $(x, y)$ change systematically from $(0.335,0.360)$ to $(0.282$, $0.330)$. It is worth pointing out that when the $\mathrm{OH}^{-}$concentration is $2 \mathrm{~mol} \mathrm{~L}^{-1}$, the ideal white UCL is achieved for the first time in the $\mathrm{ZnO}: \mathrm{Yb} / \mathrm{Tm}$ nanoparticles with color coordinates of $(0.308,0.330)$, which is very close to the standard white-light chromaticity coordinates of $(0.33,0.33)$. Therefore, the $\mathrm{OH}^{-}$concentration can not only control the $1 \mathrm{D}$ growth of nanorods, but also significantly enhances the green DSL emission, further affecting the white UCL output.

\section{CONCLUSION}

In summary, we presented a novel way of generating the white UCL via $\mathrm{Yb} / \mathrm{Tm}$ double-doped $\mathrm{ZnO}$ SNCs. The oxygen vacancies of the host $\mathrm{ZnO}$ SNCs play an important role as defecting states to provide the green UCL emission, while the doping of $\mathrm{Yb} / \mathrm{Tm}$ lanthanide ions provides the blue and red UCL emissions. Interestingly, the $1 \mathrm{D}$ growth of pencil-shaped nanorods results in larger aspect ratio in these UCNPs systems, and results in a significantly enhanced intensity of green DSL emission as compared with that from the 2D growth of UCNPs, thus providing a facile and effective approach to obtain an excellent white UCL emission. Moreover, the oxygen vacancy states of $\mathrm{ZnO}$ nanocrystals provide the energy for the transition of $\mathrm{Ln}^{3+}(\mathrm{Yb} / \mathrm{Tm})$ ions. Depending on the intermediate level of the ET process, a strong white UCL emission is obtained for the first time due to the strong blue and red emission of the doped nanocrystals. Our work offers a new way to achieve the white UCL emission and broaden the range of UCNPs.

Received 2 August 2017; accepted 5 September 2017; published online 27 November 2017

1 Liu Y, Tu D, Zhu H, et al. Lanthanide-doped luminescent nanobioprobes: from fundamentals to biodetection. Nanoscale, 2013, 5: 1369-1384

2 Wilhelm S, Kaiser M, Würth C, et al. Water dispersible upcon- verting nanoparticles: effects of surface modification on their luminescence and colloidal stability. Nanoscale, 2015, 7: 1403-1410

3 Wang M, Abbineni G, Clevenger A, et al. Upconversion nanoparticles: synthesis, surface modification and biological applications. Nanomed-Nanotech Biol Med, 2011, 7: 710-729

4 Wang L, Yan R, Huo Z, et al. Fluorescence resonant energy transfer biosensor based on upconversion-luminescent nanoparticles. Angew Chem Int Ed, 2005, 44: 6054-6057

5 Chen $\mathrm{Z}$, Chen $\mathrm{H}, \mathrm{Hu} \mathrm{H}$, et al. Versatile synthesis strategy for carboxylic acid-functionalized upconverting nanophosphors as biological labels. J Am Chem Soc, 2008, 130: 3023-3029

6 Cui HH, Valdez JG, Steinkamp JA, et al. Fluorescence lifetimebased discrimination and quantification of cellular DNA and RNA with phase-sensitive flow cytometry. Cytometry, 2003, 52A: 46-55

7 Steemers FJ, Ferguson JA, Walt DR. Screening unlabeled DNA targets with randomly ordered fiber-optic gene arrays. Nat Biotechnol, 2000, 18: 91-94

8 Han M, Gao X, Su JZ, et al. Quantum-dot-tagged microbeads for multiplexed optical coding of biomolecules. Nat Biotechnol, 2001, 19: 631-635

9 Creran B, Yan B, Moyano DF, et al. Laser desorption ionization mass spectrometric imaging of mass barcoded gold nanoparticles for security applications. Chem Commun, 2012, 48: 4543-4545

10 Zhang F, Haushalter RC, Haushalter RW, et al. Rare-earth upconverting nanobarcodes for multiplexed biological detection. Small, 2011, 7: 1972-1976

11 Cen Y, Wu YM, Kong XJ, et al. Phospholipid-modified upconversion nanoprobe for ratiometric fluorescence detection and imaging of phospholipase $\mathrm{d}$ in cell lysate and in living cells. Anal Chem, 2014, 86: 7119-7127

12 Liu J, Cheng J, Zhang Y. Upconversion nanoparticle based LRET system for sensitive detection of MRSA DNA sequence. Biosens Bioelectron, 2013, 43: 252-256

13 Zhang Y, Tang Y, Liu X, et al. A highly sensitive upconverting phosphors-based off-on probe for the detection of glutathione. Sensors Actuators B-Chem, 2013, 185: 363-369

$14 \mathrm{Yu} \mathrm{M}$, Lin J, Wang Z, et al. Fabrication, patterning, and optical properties of nanocrystalline $\mathrm{YVO}_{4}: \mathrm{A}\left(\mathrm{A}=\mathrm{Eu}^{3+}, \mathrm{Dy}^{3+}, \mathrm{Sm}^{3+}, \mathrm{Er}^{3+}\right)$ phosphor films via sol-gel soft lithography. Chem Mater, 2002, 14: 2224-2231

15 Zhang F, Braun GB, Shi Y, et al. Fabrication of Ag@SiO $@ \mathrm{Y}_{2} \mathrm{O}_{3}$ :Er nanostructures for bioimaging: tuning of the upconversion fluorescence with silver nanoparticles. J Am Chem Soc, 2010, 132: 2850-2851

16 Zhang F, Wan Y, Yu T, et al. Uniform nanostructured arrays of sodium rare-earth fluorides for highly efficient multicolor upconversion luminescence. Angew Chem Int Ed, 2007, 46: 7976-7979

17 Liu Y, Tu D, Zhu H, et al. Lanthanide-doped luminescent nanoprobes: controlled synthesis, optical spectroscopy, and bioapplications. Chem Soc Rev, 2013, 42: 6924

18 Gorris HH, Wolfbeis OS. Photonen aufkonvertierende nanopartikel zur optischen codierung und zum multiplexing von zellen, biomolekülen und mikrosphären. Angew Chem, 2013, 125: 36683686

19 Shan J, Kong W, Wei R, et al. An investigation of the thermal sensitivity and stability of the $\beta-\mathrm{NaYF}_{4}: \mathrm{Yb}, \mathrm{Er}$ upconversion nanophosphors. J Appl Phys, 2010, 107: 054901-054901

$20 \mathrm{Yu} \mathrm{W}, \mathrm{Xu} \mathrm{W}$, Song $\mathrm{H}$, et al. Temperature-dependent upconversion luminescence and dynamics of $\mathrm{NaYF}_{4}: \mathrm{Yb}^{3+} / \mathrm{Er}^{3+}$ nanocrystals: influence of particle size and crystalline phase. Dalton Trans, 2014, 
43: 6139-6147

21 Li Z, Wang L, Wang Z, et al. Modification of $\mathrm{NaYF}_{4}: \mathrm{Yb}, \mathrm{Er} @ \mathrm{SiO}_{2}$ nanoparticles with gold nanocrystals for tunable green-to-red upconversion emissions. J Phys Chem C, 2011, 115: 3291-3296

22 Zhao J, Lu Z, Yin Y, et al. Upconversion luminescence with tunable lifetime in $\mathrm{NaYF}_{4}: \mathrm{Yb}, \mathrm{Er}$ nanocrystals: role of nanocrystal size. Nanoscale, 2013, 5: 944-952

$23 \mathrm{Lu} \mathrm{Y,} \mathrm{Lu} \mathrm{J,} \mathrm{Zhao} \mathrm{J,} \mathrm{et} \mathrm{al.} \mathrm{On-the-fly} \mathrm{decoding} \mathrm{luminescence} \mathrm{life-}$ times in the microsecond region for lanthanide-encoded suspension arrays. Nat Commun, 2014, 5: 3741

24 Mahalingam V, Naccache R, Vetrone F, et al. Preferential suppression of high-energy upconverted emissions of $\mathrm{Tm}^{3+}$ by $\mathrm{Dy}^{3+}$ ions in $\mathrm{Tm}^{3+} / \mathrm{Dy}^{3+} / \mathrm{Yb}^{3+}$-doped $\mathrm{LiYF}_{4}$ colloidal nanocrystals. Chem Commun, 2011, 47: 3481-3483

25 Yang $\mathrm{X}, \mathrm{Li} \mathrm{Q}$, Liu Z, et al. Pressure-induced amorphization in $\mathrm{Gd}_{2} \mathrm{O}_{3} / \mathrm{Er}^{3+}$ nanorods. J Phys Chem C, 2013, 117: 8503-8508

26 Wang X, Kong X, Yu Y, et al. Effect of annealing on upconversion luminescence of $\mathrm{ZnO}: \mathrm{Er}^{3+}$ nanocrystals and high thermal sensitivity. J Phys Chem C, 2007, 111: 15119-15124

27 Luo W, Liu Y, Chen X. Lanthanide-doped semiconductor nanocrystals: electronic structures and optical properties. Sci China Mater, 2015, 58: 819-850

28 Liu L, Chen X. Energy levels, fluorescence lifetime and Judd-Ofelt parameters of $\mathrm{Eu}^{3+}$ in $\mathrm{Gd}_{2} \mathrm{O}_{3}$ nanocrystals. Nanotechnology, 2007, 18: 255704

29 Fan F, Feng Y, Tang P, et al. Synthesis and gas sensing performance of dandelion-like $\mathrm{ZnO}$ with hierarchical porous structure. Ind Eng Chem Res, 2014, 53: 12737-12743

30 Li Y, Wang R, Xu Y, et al. Structural characterizations and upconversion emission in $\mathrm{Yb}^{3+} / \mathrm{Tm}^{3+}$ co-doped $\mathrm{ZnO}$ nanocrystals by tri-doping with $\mathrm{Ga}^{3+}$ ions. RSC Adv, 2016, 6: 111052-111059
31 Liu Y, Luo W, Li R, et al. Near-infrared luminescence of $\mathrm{Nd}^{3+}$ and $\mathrm{Tm}^{3+}$ ions doped $\mathrm{ZnO}$ nanocrystals. Opt Express, 2009, 17: $9748-$ 9753

32 Zeng X, Yuan J, Wang Z, et al. Nanosheet-based microspheres of $\mathrm{Eu}^{3+}$-doped $\mathrm{ZnO}$ with efficient energy transfer from $\mathrm{ZnO}$ to $\mathrm{Eu}^{3+}$ at room temperature. Adv Mater, 2007, 19: 4510-4514

33 Frindell KL, Bartl MH, Popitsch A, et al. Sensitized luminescence of trivalent europium by three-dimensionally arranged anatase nanocrystals in mesostructured titania thin films. Angew Chem Int Ed, 2002, 41: 959-962

34 Jayalakshmi G, Saravanan K, Balasubramanian T. Impact of thiol and amine functionalization on photoluminescence properties of ZnO films. J Lumin, 2013, 140: 21-25

35 Chen D, Wang Y, Zheng K, et al. Bright upconversion white light emission in transparent glass ceramic embedding $\mathrm{Tm}^{3+} / \mathrm{Er}^{3+} / \mathrm{Yb}^{3+}$ : $\beta$-YF3 nanocrystals. Appl Phys Lett, 2007, 91: 251903

36 Li Y, Li Y, Wang R, et al. Enhancing upconversion luminescence by annealing processes and the high-temperature sensing of $\mathrm{ZnO}$ : $\mathrm{Yb} / \mathrm{Tm}$ nanoparticles. New J Chem, 2017, 41: 7116-7122

Acknowledgements This work was supported by the National Natural Science Foundation of China (11374080).

Author contributions $\mathrm{Li} \mathrm{Y}$ designed and engineered the samples, performed the experiments and data analysis, and wrote the paper. Li Y conceived the post-fabrication tuning of random modes, and wrote the paper. Wang $\mathrm{R}$ performed the data analysis, and wrote the paper. $\mathrm{Xu} \mathrm{Y}$ contributed to the theoretical analysis. All authors contributed to the general discussion.

Conflict of interest The authors declare that they have no conflict of interest. 


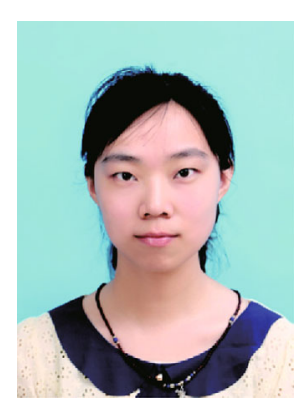

Yuemei Li is a doctor of material chemistry at Harbin Institute of Technology. Her research is focused on the preparation of nanoparticles doped with rare earth ions, and their luminescence properties for application in biological probes and optical thermometry.

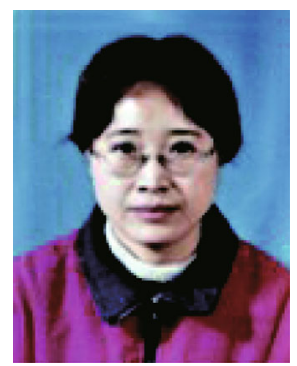

Rui Wang is a professor of chemistry. She has authored more than 50 peer review papers on topics of the growth of nanoparticles and single crystals, and the development of luminescent materials. Her current research interests include the application of upconverting luminescent materials in biological probes, and optical thermometry based on upconverting luminescent materials doped with rare earth ions.

\section{实现基于缺陷能级稀土双掺氧化锌上转换发光}

李月梅, 李永梅 ${ }^{2}$, 王锐 ${ }^{1 *}$, 徐衍岭 ${ }^{1}$

摘要 上转换白光由红色、绿色和蓝色组成, 而上转换白光通常是通过复杂的三掺杂稀土离子如 $\mathrm{Yb}^{3+} 、 \mathrm{Er}^{3+}$ 和 $\mathrm{Tm}^{3+}$ 实现的. 本文报道了一 个新型材料, 通过 $\mathrm{Yb}^{3+} 、 \mathrm{Tm}^{3+}$ 双掺 $\mathrm{ZnO}$ 实现上转换白光输出. 体系获得 $475 \mathrm{~nm}\left({ }^{1} \mathrm{G}_{4} \rightarrow{ }^{3} \mathrm{H}_{6}\right)$ 上转换蓝光和 $652 \mathrm{~nm}\left({ }^{1} \mathrm{G}_{4} \rightarrow{ }^{3} \mathrm{~F}_{4}\right)$ 上转换红光, 上转 换绿光发射源于 $\mathrm{ZnO}$ 基质材料缺陷(氧空位)发光. 此外, 通过调节 $\mathrm{OH}^{-}$的浓度可以调控纳米材料形貌. 尤其是铅笔状结构纳米棒由于表面 具有高浓度的氧空位, 实现了上转换绿光辐射. 同时氧空位缺陷作为能量传递过程的中间态能级, 提高了上转换蓝光以及上转换红光的发 光强度. 我们的研究首次将缺陷发光机理和上转换发光机理相结合, 为实现上转换白光输出开辟了新道路. 